\title{
Hypercalcemia in Upper Urinary Tract Urothelial Carcinoma: A Case Report and Literature Review
}

\author{
Keiko Asao, ${ }^{1}$ Jonathan B. McHugh, ${ }^{2}$ David C. Miller, ${ }^{3}$ and Nazanene H. Esfandiari ${ }^{4}$ \\ ${ }^{1}$ Division of Metabolism, Endocrinology \& Diabetes, Department of Internal Medicine, The University of Michigan, \\ Brehm Tower Room 5107, SPC 5714, 1000 Wall Street, Ann Arbor, MI 48105-1912, USA \\ ${ }^{2}$ Department of Pathology, The University of Michigan, 1500 E. Medical Center Drive, Room 2G332 UH/Box 0054, \\ Ann Arbor, MI 48109-0054, USA \\ ${ }^{3}$ Department of Urology, The University of Michigan, Building 16, 1st Floor, Room 108E, 2800 Plymouth Road, Ann Arbor, \\ MI 48109-2800, USA \\ ${ }^{4}$ Division of Metabolism, Endocrinology \& Diabetes, Department of Internal Medicine, The University of Michigan, \\ Domino's Farms, Lobby C, Suite 1300, 24 Frank Lloyd Wright Drive, Ann Arbor, MI 48106-0451, USA \\ Correspondence should be addressed to Keiko Asao; kasao@med.umich.edu
}

Received 15 December 2012; Accepted 8 January 2013

Academic Editors: C. Capella, W. V. Moore, Y. Moriwaki, and R. Swaminathan

Copyright @ 2013 Keiko Asao et al. This is an open access article distributed under the Creative Commons Attribution License, which permits unrestricted use, distribution, and reproduction in any medium, provided the original work is properly cited.

Objective. We here report a patient with upper urinary tract urothelial carcinoma with hypercalcemia likely due to elevated 1,25-dihydroxyvitamin D. Methods. We present a clinical case and a summary of literature search. Results. A 57-year-old man, recently diagnosed with a left renal mass, for which a core biopsy showed renal cell carcinoma, was admitted for hypercalcemia of $11.0 \mathrm{mg} / \mathrm{mL}$ He also had five small right lung nodules with a negative bone scan. Both intact parathyroid hormone and parathyroid hormone-related peptide were appropriately low, and 1,25-dihydroxyvitamin D was elevated at $118 \mathrm{pg} / \mathrm{dL}$. The patient's calcium was normalized after hydration, and he underwent radical nephrectomy. On the postoperative day 6, a repeat 1,25-dihydroxyvitamin D was $24 \mathrm{pg} / \mathrm{mL}$ with a calcium of $8.1 \mathrm{mg} / \mathrm{dL}$. Pathology showed a $6 \mathrm{~cm}$ high-grade urothelial carcinoma with divergent differentiation. We identified a total of 27 previously reported cases with hypercalcemia and upper tract urothelial carcinoma in English. No cases have a documented elevated 1,25-dihydroxyvitamin D level. Conclusion. This clinical course suggests that hypercalcemia in this case is from the patient's tumor, which was likely producing 1,25-dihydroxyvitamin D. Considering the therapeutic implications, hypercalcemia in patients with upper urinary tract urothelial carcinoma should be evaluated with 1,25-dihydroxyvitamin D.

\section{Introduction}

Hypercalcemia is one of the most common paraneoplastic syndromes. Although hypercalcemia is found in $13-20 \%$ of patients with renal cell carcinoma [1], reports of upper tract urothelial carcinoma complicated by hypercalcemia are sparse. This can be explained partially from the rarity of the disease: accounting for $10 \%$ of all renal tumors and 5\% of all urothelial malignancies and with roughly 3,000 newly diagnosed cases in the USA in 2007 [2]. Little has been known about the mechanism of hypercalcemia associated with upper tract urothelial carcinoma. Here, we report a case of upper tract urothelial carcinoma, where the cause of hypercalcemia was presumably due to elevated 1,25-dihydroxyvitamin D.

\section{Case}

A 57-year-old man with a history of hypertension presented with left flank pain, anorexia, and $23 \mathrm{~kg}$ of weight loss over two months. He did not have gross hematuria or fever. An abdominal computed tomography (CT) scan revealed a $6 \times 4.8 \mathrm{~cm}$ mass arising from the medial aspect of the lower pole of the left kidney, with retroperitoneal lymph node enlargement, and tumor nodularity spreading along the anterior pararenal fascia. The left renal vein and inferior vena cava were patent. A core biopsy of the left kidney mass concluded a high-grade, clear cell renal cell carcinoma. Further staging evaluation demonstrated five small right lung 
nodules by a chest CT scan felt to be metastatic lesions. There was no metabolically active bone lesion on bone scintigraphy.

The patient was scheduled for left radical nephrectomy with retroperitoneal lymph node dissection. His preoperative workup revealed mild hyponatremia, mild hyperkalemia, and hypercalcemia. He complained of nausea without vomiting and constipation for 3 weeks, which he attributed to narcotic use for pain control. He did not have any change in mood. He had no history of kidney stones or fractures. The review of systems was positive for dyspnea on exertion, but otherwise noncontributory. He had no other significant medical history. The family history was unremarkable. He quit smoking 20 years ago and was a social drinker. He was a truck driver.

His medications included atenolol $100 \mathrm{mg}$ daily and lisinopril $5 \mathrm{mg}$ daily, but he was not taking them consistently. His other home medications included acetaminophen/hydrocodone as needed for pain. He had never been on hydrochlorothiazide or any over-the-counter medications or herbal supplements. Prior to admission, he reported fluid intake of approximately $3.5 \mathrm{~L}$ per day.

Physical examination showed a man with a height of $165 \mathrm{~cm}$ and weight of $94.1 \mathrm{~kg}$. His vital signs were as follows: blood pressure 135/69 $\mathrm{mmHg}$, pulse $99 /$ minute, respiratory rate $20 /$ minute, and body temperature $36.7^{\circ} \mathrm{C}$. He was well developed, well nourished, and without acute distress. He was alert and oriented, and his affect appeared normal. His tongue was moist. His thyroid examination was normal. The chest was clear to auscultation bilaterally. Cardiovascular examination revealed normal S1 and S2 sounds and a regular rate and rhythm without murmur, gallop, or rubs. The abdomen was soft and nondistended, although there was a palpable, fist-sized mass in the left lower quadrant. Bowel sounds were normal. There was no lower extremity edema. A neurological examination was unremarkable. There was no skin rash.

His laboratory data at admission are shown in Table 1 . At admission, sodium was $129 \mathrm{mmol} / \mathrm{L}$, potassium $5.2 \mathrm{mmol} / \mathrm{L}$, and calcium $11.0 \mathrm{mg} / \mathrm{dL}$ with albumin $3.6 \mathrm{~g} / \mathrm{dL}$. Both intact PTH (immunochemiluminometric assay) and PTHrP (immunochemiluminometric assay) were appropriately low for his hypercalcemia. His 1,25-dihydroxyvitamin D level was $118 \mathrm{pg} / \mathrm{dL}$ (radioimmunoassay, reference range 18-72), which was inappropriately high for his hypercalcemia. A random cortisol of $34.8 \mathrm{mcg} / \mathrm{dL}$ (reference range 3.0-13.0 in the afternoon) ruled out adrenal insufficiency, as a cause of hyponatremia, hyperkalemia, and hypercalcemia. Initially, $0.9 \% \mathrm{NaCl}$ was given intravenously at $125 \mathrm{~mL} /$ hour to correct hypercalcemia. Two days later, serum calcium was normalized and he was discharged. Since his random glucose was elevated a few times, glycated hemoglobin was checked and he was diagnosed with diabetes mellitus for the first time.

The patient was readmitted two days later for his scheduled left open nephrectomy with retroperitoneal lymph node dissection. At that time, calcium was again elevated at $10.6 \mathrm{mg} / \mathrm{dL}$ with an albumin of 3.6 grams/dL. The next day, he underwent his scheduled surgery. Intraoperatively, extensive left renal tumor with the involvement of the colonic mesentery, psoas muscle, and retroperitoneal lymphadenopathy was found. Therefore, left radical nephrectomy with left adrenalectomy, retroperitoneal lymph node resection, and en

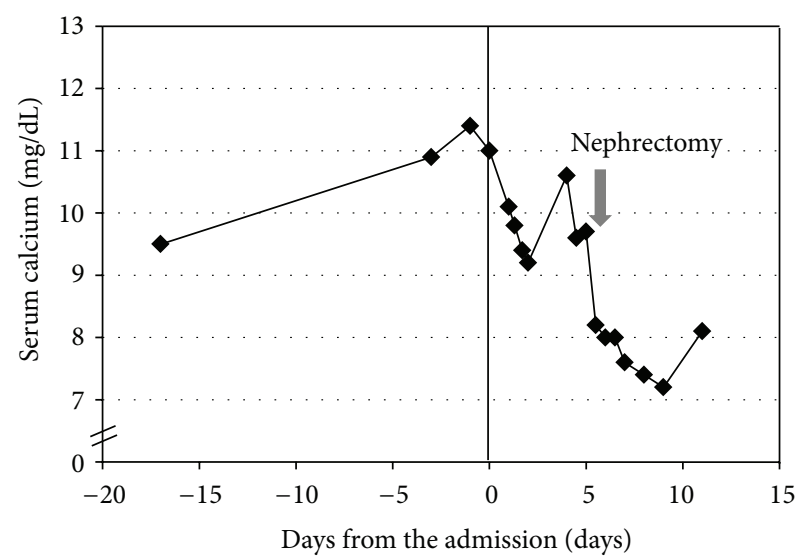

Figure 1: Trends of serum calcium. Note that serum calcium is not corrected for albumin level. Albumin on admission was 3.6 grams/dL, while albumin before the nephrectomy was 2.8 grams/dL.

bloc colon resection was performed. Due to the significant blood loss $(1,600 \mathrm{~mL})$ during the operation, the patient received 1 unit of packed red blood cell transfusion and stayed in the surgical intensive care unit for a day. Postoperatively, the patient's calcium remained low (Figure 1). On the postoperative day 6 , a repeat 1,25 -dihydroxyvitamin $\mathrm{D}$ showed a level of $24 \mathrm{pg} / \mathrm{mL}$ with a calcium of $8.1 \mathrm{mg} / \mathrm{dL}$. He was discharged home on the postoperative day 6. Pathology showed a $6 \mathrm{~cm}$ high-grade urothelial carcinoma of the renal pelvis and ureter with divergent differentiation, including $80 \%$ clear cell squamous differentiation and 5\% sarcomatoid differentiation. The tumor had invaded through the kidney into the perinephric fat. The margin was positive and extensive angiolymphatic invasion was identified as well. Two lymph nodes were examined and both were positive for metastatic carcinoma.

About three weeks after the discharge, a repeat chest CT scan showed significant increase in size and number of pulmonary nodules. He was referred to a local oncologist for palliative chemotherapy. He died five weeks after discharge.

\section{Discussion}

We report a case of upper tract urothelial carcinoma with hypercalcemia. At the time of hypercalcemia, intact PTH was appropriately suppressed, and PTHrP was not elevated. 1,25-dihydroxyvitamin $\mathrm{D}$, on the other hand, was markedly elevated. The hypercalcemia resolved soon after the removal of the tumor, and the patient's 1,25-dihydroxyvitamin D level decreased to the normal range. This clinical course suggests that the hypercalcemia in this case was caused by the patient's tumor, which was likely producing 1,25-dihydroxyvitamin D.

Because upper urinary tract urothelial carcinoma is relatively uncommon, there is limited information available for the mechanisms of hypercalcemia associated with this type of tumor. 1,25-Dihydroxyvitamin D is a known cause of hypercalcemia in disorders such as lymphoma [28], granulomatous diseases $[29,30]$, and malignancy [31-33], including renal cell 
TABLE 1: Clinical laboratory data.

\begin{tabular}{|c|c|c|c|c|}
\hline & Admission & After surgery & Reference range & Unit \\
\hline Sodium & 129 & 132 & $136-146$ & $\mathrm{mmol} / \mathrm{L}$ \\
\hline Potassium & 5.2 & 4.7 & $3.5-5.0$ & $\mathrm{mmol} / \mathrm{L}$ \\
\hline Chloride & 92 & 102 & $98-108$ & $\mathrm{mmol} / \mathrm{L}$ \\
\hline Bicarbonate & 28 & 25 & $22-34$ & $\mathrm{mmol} / \mathrm{L}$ \\
\hline BUN & 16 & 10 & $8-20$ & $\mathrm{mg} / \mathrm{dL}$ \\
\hline Creatinine & 0.9 & 0.7 & $0.7-1.3$ & $\mathrm{mg} / \mathrm{dL}$ \\
\hline Glucose & 152 & 209 & $73-110$ & $\mathrm{mg} / \mathrm{dL}$ \\
\hline Calcium & 11.0 & 8.2 & $8.6-10.3$ & $\mathrm{mg} / \mathrm{dL}$ \\
\hline Phosphorous & 4.0 & 4.4 & $2.7-4.6$ & $\mathrm{mg} / \mathrm{dL}$ \\
\hline Magnesium & 2.3 & 1.6 & $1.5-2.4$ & $\mathrm{mg} / \mathrm{dL}$ \\
\hline Albumin & 3.6 & & $3.5-4.9$ & $\mathrm{~g} / \mathrm{dL}$ \\
\hline Ionized calcium & 1.45 & 1.30 & $1.12-1.30$ & $\mathrm{mmol} / \mathrm{L}$ \\
\hline WBC & 20.7 & 25.4 & $4.0-10.0$ & $\times 10^{3} / \mathrm{mm}^{3}$ \\
\hline Neutrophil & 87.6 & 86.2 & $36.0-75.0$ & $\%$ \\
\hline Lymphocyte & 7.5 & 8.6 & $20.0-50.0$ & $\%$ \\
\hline Monocyte & 4.1 & 3.9 & $3.0-10.0$ & $\%$ \\
\hline Eosinophil & 0.4 & 0.8 & $0.0-4.0$ & $\%$ \\
\hline Basophil & 0.4 & 0.5 & $0.0-2.0$ & $\%$ \\
\hline Hemoglobin & 12.6 & 10.9 & $13.0-17.3$ & $\mathrm{~g} / \mathrm{dL}$ \\
\hline Hematocrit & 37.3 & 32.9 & $39.0-50.2$ & $\%$ \\
\hline Platelet & 361 & 499 & $150-450$ & $\times 10^{3} / \mathrm{mm}^{3}$ \\
\hline Intact PTH & 2 & & $10-65$ & $\mathrm{pg} / \mathrm{mL}$ \\
\hline PTHrP & 1.1 & & $<2.0$ & $\mathrm{pmol} / \mathrm{L}$ \\
\hline 25-Hydroxyvitamin D & 51 & & $25-80$ & $\mathrm{ng} / \mathrm{mL}$ \\
\hline 1,25-Dihydroxyvitamin D & 118 & 24 & $18-72$ & $\mathrm{pg} / \mathrm{mL}$ \\
\hline Serum osmolality & 276 & & $269-298$ & $\operatorname{mosm} / \mathrm{K}$ \\
\hline Urine osmolality & 589 & & $300-1300$ & $\operatorname{mosm} / \mathrm{K}$ \\
\hline Urine sodium & 86 & & & $\mathrm{mmol} / \mathrm{L}$ \\
\hline HbAlc & 8.4 & & $3.8-6.4$ & $\%$ \\
\hline TSH & 1.53 & & $0.30-5.50$ & $\mathrm{mIU} / \mathrm{L}$ \\
\hline Serum cortisol & 34.8 & & $3.0-13.0^{*}$ & $\mathrm{mcg} / \mathrm{dL}$ \\
\hline
\end{tabular}

BUN: blood urea nitrogen, WBC: white blood cell.

${ }^{*}$ Reference range in the afternoon.

carcinoma $[34,35]$. Lee et al. summarized five cases of previously published case reports of humoral hypercalcemia associated with the renal pelvis carcinoma in 1988 [15]. We identified 27 cases previously published in English, in addition to our case (Table 2). To our knowledge, our report presents the first case of hypercalcemia with upper tract urothelial carcinoma with a documented elevated 1,25-dihydroxyvitamin D level. The cases with a suppressed PTH without an elevation of PTHrP $[9,16,21,22,25]$ could have been from an elevated 1,25-dihydroxyvitamin $\mathrm{D}$ if it had been measured. Some other cases $[3,11,26]$ might have proven an elevated 1,25dihydroxyvitamin $\mathrm{D}$, if the full workup was available.

It is likely that 1,25 -dihydroxyvitamin $\mathrm{D}$-associated hypercalcemia is due to the increased conversion of 25-hydroxyvitamin $\mathrm{D}$ to 1,25-dihydroxyvitamin $\mathrm{D}$ by $1 \alpha$-hydroxylase activity. $1 \alpha$-Hydroxylase was originally thought to be exclusively expressed at the proximal tubules of the kidney [36], although a recent work showed diffuse expression along the nephron [37] and extrarenally [38]. It is our speculation that the tumor in this case overexpressed $1 \alpha$-hydroxylase, resulting in high 1,25 -dihydroxyvitamin D levels, but we were unable to stain $1 \alpha$-hydroxylase on the specimen.

The hypercalcemia in this case resolved after the removal of the tumor, which is consistent with most previous case reports. Had our case not been operative, or the hypercalcemia recurred after nephrectomy, glucocorticoid treatment could have been an option.

In addition to hypercalcemia, we make a note that this case had leukocytosis. There are case reports of upper urothelial carcinoma associated with leukocytosis $[23,24]$, one of which reported the elevation of serum granulocyte 


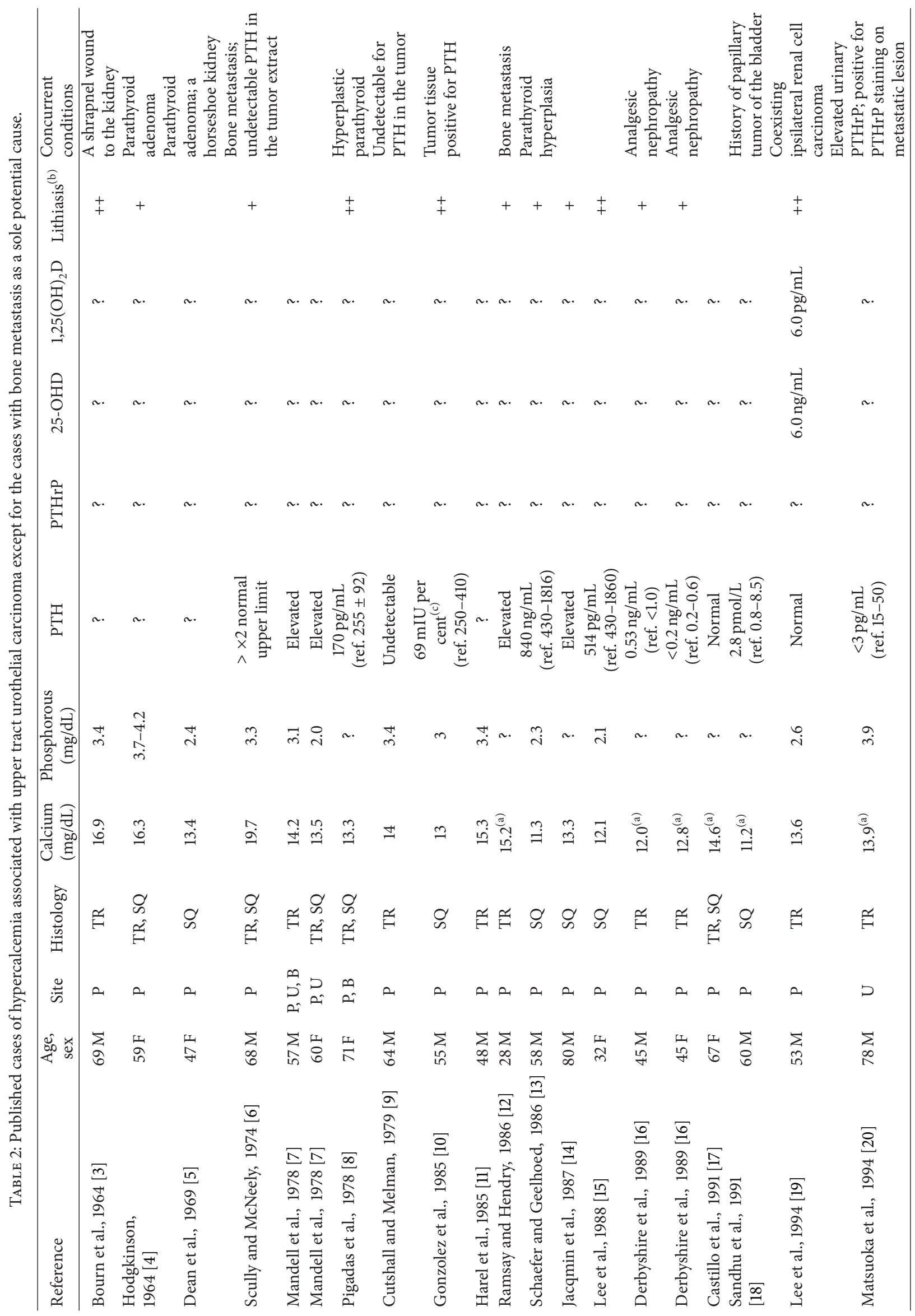




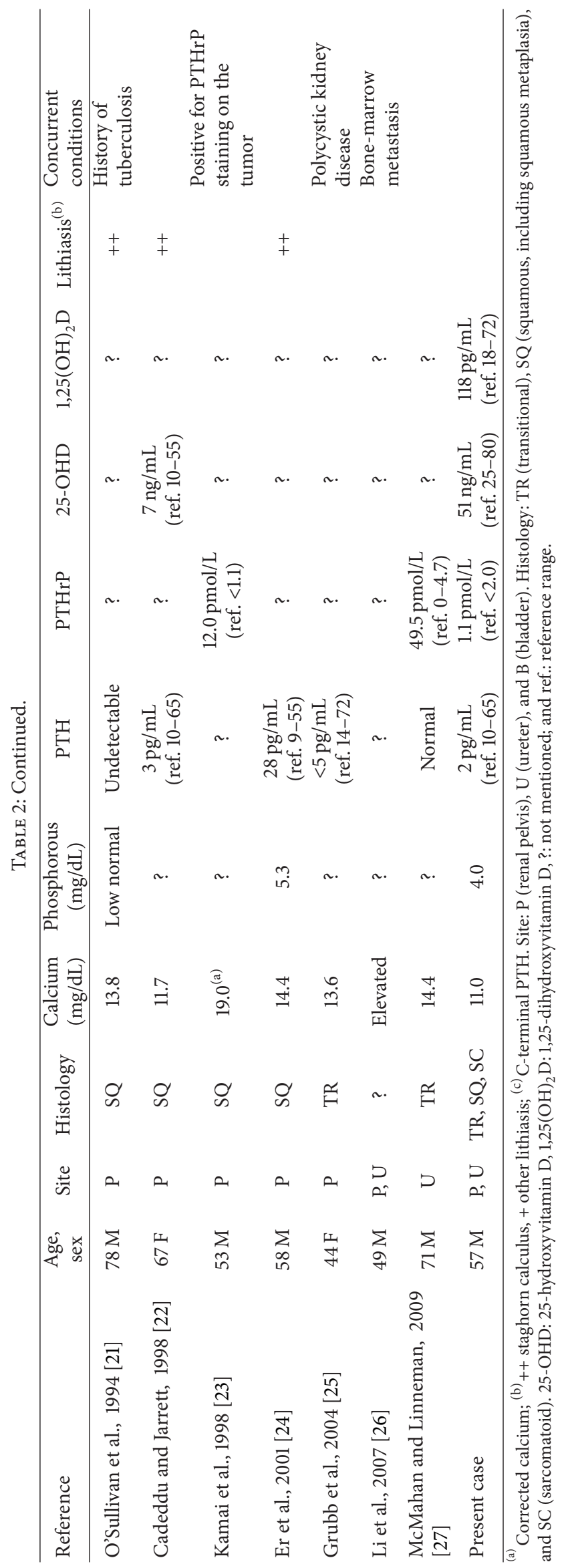


colony-stimulating factor (G-CSF) [23]. In our case, leukocytosis might be multifactorial.

In conclusion, we report an uncommon case of hypercalcemia from high 1,25-dihydroxyvitamin $\mathrm{D}$ in an upper urinary tract urothelial carcinoma possibly related to the overexpression of $1 \alpha$-hydroxylase, which resolved after nephrectomy. Considering the therapeutic implications, hypercalcemia in upper urinary tract urothelial carcinoma should be evaluated with 1,25-dihydroxyvitamin D.

\section{Conflict of Interests}

The authors declare no conflict of interests.

\section{References}

[1] G. S. Palapattu, B. Kristo, and J. Rajfer, "Paraneoplastic syndromes in urologic malignancy: the many faces of renal cell carcinoma," Reviews in Urology, vol. 4, no. 4, pp. 163-170, 2002.

[2] N. D. Smith, "Management of upper tract urothelial carcinoma," Advances in Urology, Article ID 492462, 2009.

[3] H. H. Bourne, R. E. Tremblay, and J. S. Ansell, "Stupor, hypercalcemia and carcinoma of the renal pelvis," The New England journal of medicine, vol. 271, pp. 1005-1006, 1964.

[4] A. Hodgkinson, "Hyperparathyroidism and cancer," British medical journal, vol. 2, no. 5406, 1964.

[5] A. C. Dean, A. T. Lambie, and A. A. Shivas, "Hypercalcaemic crisis and squamous carcinoma of the renal pelvis," British Journal of Surgery, vol. 56, no. 5, pp. 375-379, 1969.

[6] R. E. Scully and B. U. McNeely, "Case records of the massachusetts general hospital. Weekly clinicopathological exercises. Case 40-1974," The New England Journal of Medicine, vol. 291, no. 15, pp. 780-788, 1974.

[7] J. Mandell, M. C. Magee, and F. A. Fried, "Hypercalcemia associated with uroepithelial neoplasms," Journal of Urology, vol. 119 , no. 6 , pp. $844-845,1978$.

[8] A. Pigadas, J. Chang, A. J. McGowan, and V. E. Keyloun, "Squamous cell carcinoma of the renal pelvis presenting with hypercalcemia," Journal of Urology, vol. 119, no. 1, pp. 126-128, 1978.

[9] W. Cutshall and A. Melman, "Nonparathormone-induced hypercalcemia with transitional cell carcinoma," Southern Medical Journal, vol. 72, no. 6, pp. 741-743, 1979.

[10] R. D. Gonzalez, A. Barrientos, and L. Larrodera, "Squamous cell carcinoma of the renal pelvis associated with hypercalcemia and the presence of parathyroid hormone-like substances in the tumor," Journal of Urology, vol. 133, no. 6, pp. 1029-1030, 1985.

[11] G. Harel, U. Gafter, and D. Zevin, "Hypercalcemia associated with transitional cell carcinoma without bone metastases: description of two cases," Urologia Internationalis, vol. 40, no. 3, pp. 164-165, 1985.

[12] J. W. Ramsay and W. F. Hendry, "Serum parathyroid hormone levels in the hypercalcaemia of urological malignant disease," Journal of the Royal Society of Medicine, vol. 79, no. 6, pp. 323$325,1986$.

[13] C. J. Schaefer and G. W. Geelhoed, "Hypercalcemia in squamous cell carcinoma of the renal pelvis? Parathyroid or paraendocrine in origin," The American Surgeon, vol. 52, no. 10, pp. 560-563, 1986.
[14] D. Jacqmin, C. Bollack, A. Warter, and C. Roy, "Squamous cell carcinoma of the renal pelvis and hypercalcaemia," British Journal of Urology, vol. 60, no. 6, pp. 593-594, 1987.

[15] M. Lee, R. Sharifi, and N. A. Kurtzman, "Humoral hypercalcemia due to squamous cell carcinoma of renal pelvis," Urology, vol. 32, no. 3, pp. 250-253, 1988.

[16] N. D. Derbyshire, A. W. Asscher, and P. N. Matthews, "Hypercalcaemia as a manifestation of malignant urothelial change in analgesic nephropathy," Nephron, vol. 52, no. 1, pp. 79-80, 1989.

[17] J. M. Castillo, J. J. Illarramendi, A. Santiago, and J. L. Sebastian, "Low dose epirubicin for hypercalcemia associated with renal pelvis carcinoma," Archivos Españoles de Urología, vol. 44, no. 1, pp. 97-99, 1991.

[18] D. P. Sandhu, G. Cooksey, K. O’Reilly, and J. Gordon-Smart, "Squamous cell carcinoma of the renal pelvis associated with urinary diversion and humoral hypercalcaemic malignancy syndrome," Journal of the Royal College of Surgeons of Edinburgh, vol. 36, no. 3, pp. 192-194, 1991.

[19] J. W. Lee, M. J. Kim, J. H. Song, J. H. Kim, and J. M. Kim, "Ipsilateral synchronous renal cell carcinoma and transitional cell carcinoma," Journal of Korean Medical Science, vol. 9, no. 6, pp. 466-470, 1994.

[20] S. Matsuoka, Y. Miura, T. Kachi et al., "Humoral hypercalcemia of malignancy associated with parathyroid hormone-related protein producing transitional cell carcinoma of the ureter," Internal Medicine, vol. 33, no. 2, pp. 107-109, 1994.

[21] D. C. O'Sullivan, D. Murphy, P. Conlon, and J. Walshe, "Hypercalcaemia due to squamous cell carcinoma in a tuberculous kidney: case report and review of pathogenesis," British Journal of Urology, vol. 73, no. 1, pp. 106-107, 1994.

[22] J. A. Cadeddu and T. W. Jarrett, "Hypercalcemia associated with squamous cell carcinoma of the renal pelvis," Journal of Urology, vol. 160, no. 5, p. 1798, 1998.

[23] T. Kamai, G. Toma, H. Masuda, and D. Ishiwata, "Simultaneous production of parathyroid hormone-related protein and granulocyte colony-stimulating factor in renal pelvic cancer," Journal of the National Cancer Institute, vol. 90, no. 3, pp. 249-250, 1998.

[24] Ö. Er, H. S. Coşkun, M. Altinbaş et al., "Rapidly relapsing squamous cell carcinoma of the renal pelvis associated with paraneoplastic syndromes of leukocytosis, thrombocytosis and hypercalcemia," Urologia Internationalis, vol. 67, no. 2, pp. 175$177,2001$.

[25] R. L. Grubb, W. C. Collyer, and A. S. Kibel, “Transitional cell carcinoma of the renal pelvis associated with hypercalcemia in a patient with autosomal dominant polycystic kidney disease," Urology, vol. 63, no. 4, pp. 778-780, 2004.

[26] S. H. Li, W. T. Huang, and C. Y. Kuo, "Metastatic urothelial carcinoma of upper urinary tract," The American Journal of Hematology, vol. 82, no. 10, pp. 940-941, 2007.

[27] J. McMahan and T. Linneman, "A case of resistant hypercalcemia of malignancy with a proposed treatment algorithm," Annals of Pharmacotherapy, vol. 43, no. 9, pp. 1532-1538, 2009.

[28] J. F. Seymour, R. F. Gagel, F. B. Hagemeister, M. A. Dimopoulos, and F. Cabanillas, "Calcitriol production in hypercalcemic and normocalcemic patients with non-Hodgkin lymphoma," Annals of Internal Medicine, vol. 121, no. 9, pp. 633-640, 1994.

[29] M. Kallas, F. Green, M. Hewison, C. White, and G. Kline, "Rare causes of calcitriol-mediated hypercalcemia: a case report and literature review," Journal of Clinical Endocrinology and Metabolism, vol. 95, no. 7, pp. 3111-3117, 2010. 
[30] T. P. Jacobs and J. P. Bilezikian, "Clinical review: rare causes of hypercalcemia," Journal of Clinical Endocrinology and Metabolism, vol. 90, no. 11, pp. 6316-6322, 2005.

[31] M. Maislos, R. Sobel, and S. Shany, "Leiomyoblastoma associated with intractable hypercalcemia and elevated 1,25dihydroxycholecalciferol levels. Treatment by hepatic enzyme induction," Archives of Internal Medicine, vol. 145, no. 3, pp. 565$567,1985$.

[32] A. Ogose, H. Kawashima, O. Morita, T. Hotta, H. Umezu, and N. Endo, "Increase in serum 1,25-dihydroxyvitamin D and hypercalcaemia in a patient with inflammatory myofibroblastic tumour," Journal of Clinical Pathology, vol. 56, no. 4, pp. 310-312, 2003.

[33] T. H. Grote and J. D. Hainsworth, "Hypercalcemia and elevated serum calcitriol in a patient with seminoma," Archives of Internal Medicine, vol. 147, no. 12, pp. 2212-2213, 1987.

[34] I. Yamamoto, N. Kitamura, and J. Aoki, "Circulating 1,25dihydroxyvitamin $\mathrm{D}$ concentrations in patients with renal cell carcinoma-associated hypercalcemia are rarely suppressed," Journal of Clinical Endocrinology and Metabolism, vol. 64, no. 1, pp. 175-179, 1987.

[35] S. B. Shivnani, J. M. Shelton, J. A. Richardson, and N. M. Maalouf, "Hypercalcemia of malignancy with simultaneous elevation in serum parath yroid hormone-related peptide and 1,25-Dihydroxyvita min D in a patient with Metastatic renal cell carcinoma," Endocrine Practice, vol. 15, no. 3, pp. 234-239, 2009.

[36] M. G. Brunette, M. Chan, C. Ferriere, and K. D. Roberts, "Site of $1,25(\mathrm{OH})_{2}$ vitamin $\mathrm{D}_{3}$ synthesis in the kidney," Nature, vol. 276, no. 5685, pp. 287-289, 1978.

[37] D. Zehnder, R. Bland, E. A. Walker et al., "Expression of 25-hydroxyvitamin D3-1 $\alpha$-hydroxylase in the human kidney," Journal of the American Society of Nephrology, vol. 10, no. 12, pp. 2465-2473, 1999.

[38] D. Zehnder, R. Bland, M. C. Williams et al., "Extrarenal expression of 25-hydroxyvitamin D3-1 $\alpha$-hydroxylase," Journal of Clinical Endocrinology and Metabolism, vol. 86, no. 2, pp. 888894, 2001. 


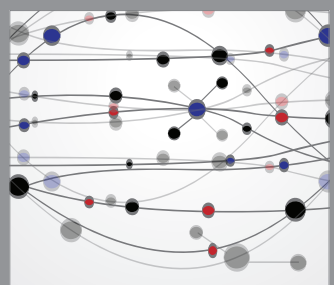

The Scientific World Journal
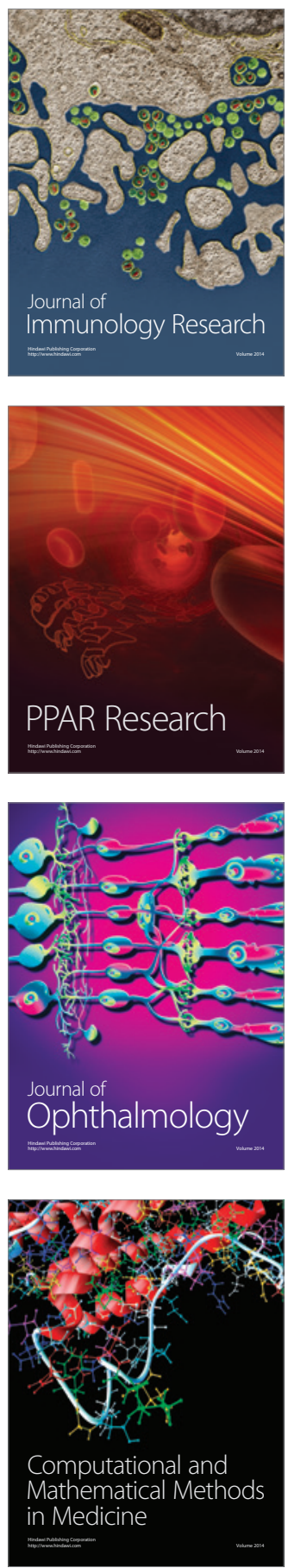

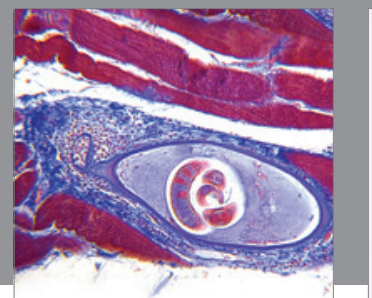

Gastroenterology

Research and Practice
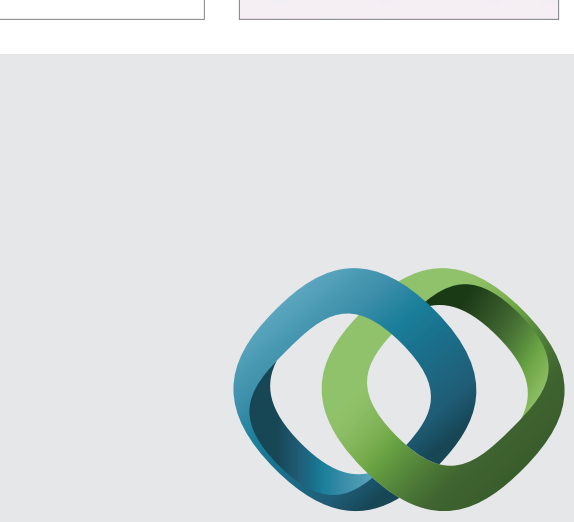

\section{Hindawi}

Submit your manuscripts at

http://www.hindawi.com
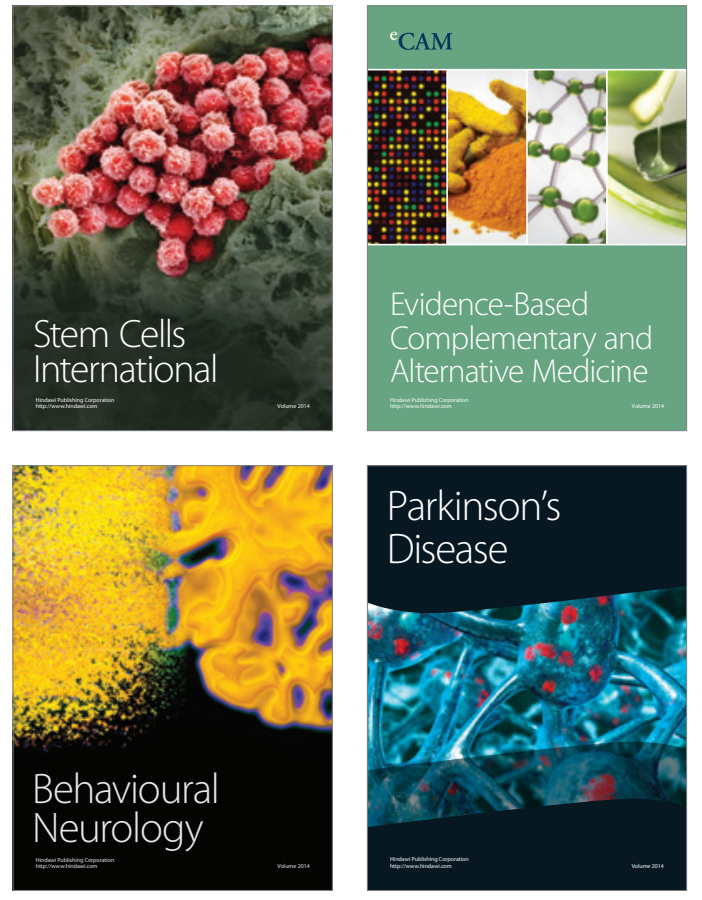
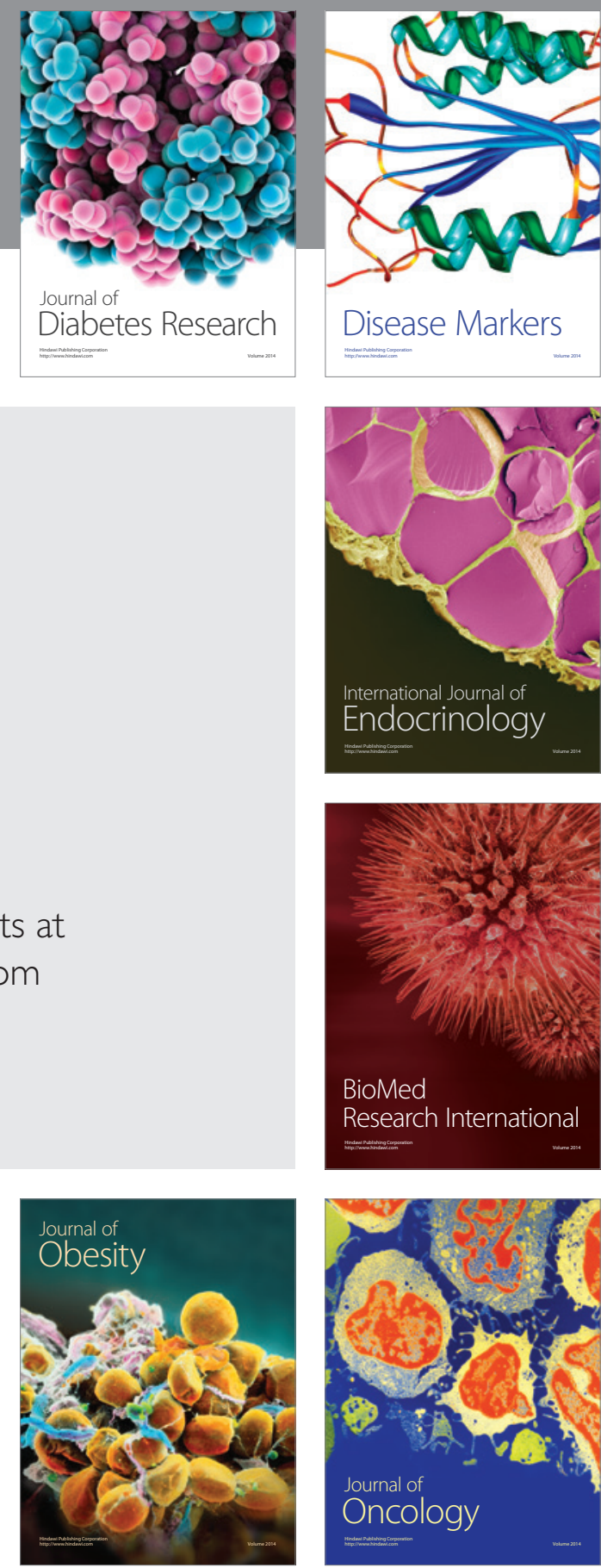

Disease Markers
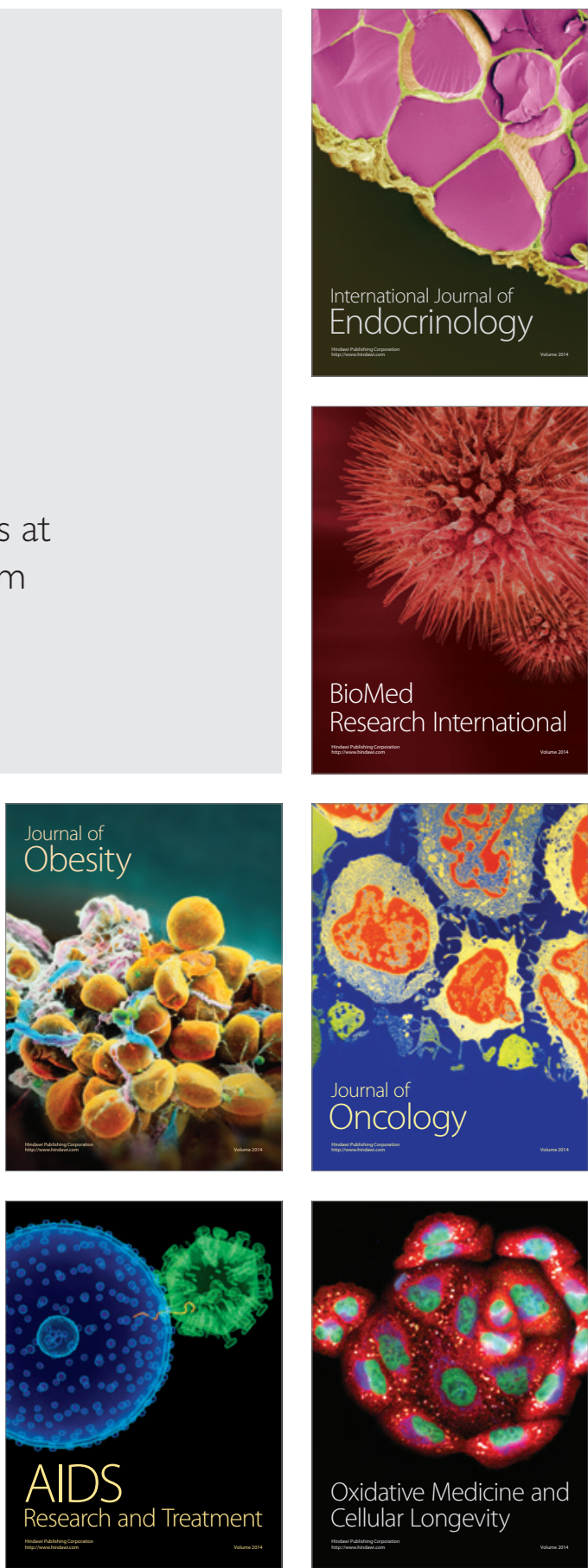